\title{
CONVERGENCE OF CULTURAL LANDSCAPE ON THE CZECH-BAVARIAN BORDER IN ŠUMAVA MTS.
}

\begin{abstract}
BREUER, T., KOLEJKA, J., MAREK, D., WERNER, E. (2010): Convergence of cultural landscape in the Czech-Bavarian border in Šmava Mts. Geografie, 115, No. 3, pp. 308-329. - Two model municipality areas on the Czech-Bavarian (German) border were examined. The objective of research was to determine the changes which land use in different types of the natural environment on both sides of the border has undergone over the last 200 years with respect to the social driving forces. The task was based on historical studies of archived materials statistical a cartographic materials, recent fieldworks and finally carried out in the GIS environment, which encompassed maps of natural landscape units of both areas and land use maps of 1829-1840, 1935-1938 and in 2002-2007. Results show a high degree of similarity in the dominance of the main forms now as output of previous development: in forests, meadows and arable land, as well as in corresponding types of units on both sides of the border. Through clustering, the development trends of all the units have been detected. These trends tend to lead toward a similar form of present land use.

KEY WORDS: environmental history - natural landscape units - land use convergence.
\end{abstract}

\section{Introduction}

European cultural landscape is undergoing changes which reflect both economic and social events and simultaneously respect the natural given conditions of the area. It is primarily environmentalists who spare no pains to be critical of the past and present changes of the Czech and Bavarian landscapes and in many cases it is difficult to challenge their opinions. Frequently the landscape development in some places in Europe is set as an example of the desired development in Czechia and Germany. However, does not spontaneous following of external trends pose a threat to the identity of the local cultural landscape? Evidence which would ground similar fears is still missing. One of the objectives of this study is thus to at least partially fill in the void created by the absence of real data necessary for drawing initial conclusions. Following example does not cover an intention to study the cultural landscape convergence in general. Its task among others is to demonstrate the important "cross-border" role of the natural environment in the land use pattern formation and development.

The areas' position on the border between states which have gone through a dramatically different sociopolitical development offers possibilities to study the emerged differences and inspires the forming of hypotheses which integrate the influence of natural, economic, social and political factors in the process of the forming of a cultural landscape. The documentation of the historical 
development of cultural landscape in the past enables us to understand the emerged differences. However, the areas' prominent position in the vicinity of a state border is only one of the factors which are reflected in the time series of the local structures of land use. When studying the chronological changes in land use we can assume that in a given area it is possible to outline, practically define and minutely describe different types of natural environment in the form of natural landscape units, i.e. natural geosystems which both in the past and today play the role of a background for human activities (Kolejka 1987, Olah 2003). The choice of a representative study area near the border proved to be a rather demanding task. It requires the choice of such areas on either side of the border which display similar natural qualities and with whose starting situation of land use in distant past we are familiar.

The Czech-Bavarian border constitutes one of the oldest and most stable borders between states in Europe, regardless to short war turbulences in 20th century. However, Šumava's vast and deep forests ("Sylva hercynica" in Roman times) never constituted an insurmountable obstacle and thus various innovations flowed in both directions and marked themselves in the landscape's face. More precise and detailed records of the real appearance of the local cultural landscape ("natural" landscape in the area can be taken into account only by high Middle Ages) date back to the 18th and most importantly to the 19th centuries, when military topographic survey of the areas on either side of the border was carried out. Similarly, reliable population census data originated at the same dates. First comparable data come from the first half of the 19th century. Since then a considerable number of sufficiently detailed and reliable census and cartographic data have been amassed. These data record the land use and its natural conditions over the last two hundred years. Modern times have provided state-of-the-art processing technologies and efficient processes of geodata collection and acquisition. GIS and remote sensing of the Earth are tools which help us answer the sensitive question of where the development of cultural landscape is heading for.

The study of cultural landscape changes on both sides of the Czech-Bavarian border are part of the Masaryk University in Brno and University of Regensburg common research project. One the project's objectives is to reveal development trends within naturally similar neighboring areas with different cultural histories.

\section{Materials and methods}

Two municipalities, Strážný (Czechia - CZ) and Philipsreuth (Germany - D) and their respective administrative areas meet the requirements of being representative and mutually comparative (Fig. 1). Both monitored areas are close neighbors on either side of the Czech-Bavarian border. The key for their choice was their analogous position on the Šumava plains and similar natural conditions as a starting point for human utilizing. The total area of the comparative units is $23.3 \mathrm{~km}^{2}$, of which Strážný covers $13.1 \mathrm{~km}^{2}$ and Philipsreuth covers $10.2 \mathrm{~km}^{2}$ (Fig. 2). For both municipalities we succeeded in acquiring analogous territorial cartographic documentation on land use which covers three historical horizons: first half of the 19th century (1829-D, 1840-CZ), period 


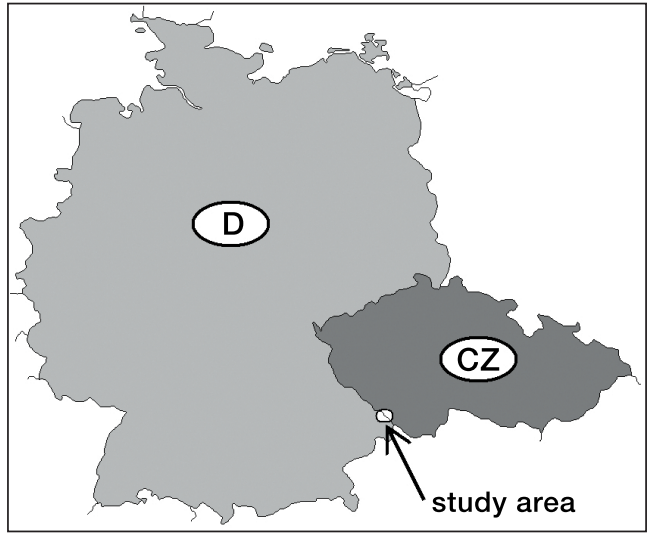

Fig. 1 - Position of the study area at the CzechGerman border (CZ - Czechia, D - Germany) before the World War 2 (1935-CZ, 1938-D) and the present state (2002-D, 2007-CZ). We have also managed to acquire relevant data on individual natural landscape components (geological environment, soil cover, climatic and humidity conditions, potential vegetation cover) despite the fact that some data had to be mapped during field trips. All the original data were in analog form and thus it was necessary to transform them into digital form, unify them and completely integrate them (as regards of format, cartographic projection, resolution, scale, concept and logical interconnection) as they came from extremely differing sources. Available statistical census data were collected where possible for the period since the beginning of the 19th century.

Needless to say that historical changes in land use constitute a traditional focus of landscape ecology research (Balej 2007; Bičík, Jeleček 2003; Naveh, Lieberman 1994). Some inspiration for the landscape ecological research of land use changes can be found in the rich recent literature dealing with land use and land cover changes (LUCC). The one side Slovenian border area was selected for the detail LUCC study by Gabrovec and Petek (2003). The problem of regional identity in border regions of Czechia treated Štěpánek (2002) and Chromý (2003). Social and economic LUCC driving forces are commonly dealt on community level (or in other larger administrative units) in many countries, e.g. in France, India, China, Russia etc. (Babu 2002, Mather 2002, Zhang 2002). Relationships between LUCC and natural territory features were studied much rarely. Such studies rely mostly on comparison between the identified LUCC changes in large research regions (countries, provinces) and individual landscape characteristics, e.g. macro/mesoclimate, sea elevation, soil fertility (see Štych 2003; Balázs, Ángyán, Podmaniczky 2002, etc.). The most detail land use change studies were carried out on the cadastral (topological) level based on changes within individual parcels (Kupková 2001, Lipský 1995). In general, until the present only very few projects dealt with LUCC on one hand and natural typological area units described with mutually balanced features as they are in the real landscape on the other hand (Kolejka 1983, Olah 2003). Modelling technologies are employed in the proposal compilation of future states of land use pattern (see Lovejoy, ed. 1973; Evans 2004). It is very useful to learn from the knowledge derived from the past development, but it cannot serve as the base for the planning of the future (Head 2000).

Geoinformation technologies have enabled scientists to carry out their research multilaterally, to integrate it with a number of additional data and to work efficiently in real time. Providing we have a profound knowledge of the natural conditions of a given area, we can determine whether the motif for changes includes also the sites' different qualities. However, historical 
landscape environmental research tends to neglect this aspect of research. A chronological (time) sequence can reveal what changes in use a given type of natural environment has undergone. Based on analogy we can clearly expect a similar development in other areas, which can prove to be an interesting topic to consider during landscape planning.

The entire area of interest lies on the "Moldau side" of the main European watershed Danube/Elbe. This divide runs along the western and southern delimitation of the interest area. The state border divides the area into two halves of an approximately identical size.

From a geomorphological point of view the area belongs to the Šumava province which is represented by the Šumava plains Highland and partly by the Trojmezenska hornatina Mts. in the east. Generally we can describe the area as highlands grounded on a strongly remodelled segments of Earth's crust which constitute a system of horsts (max. Almberg 1,139 m, min. outlet of the Wagenwasser/Hraniční stream from the area of Philipsreuth: $845 \mathrm{~m}$ in D; max. Pomezný 1,002 m, outlet of the Řasnice River from the area of Strážný: $800 \mathrm{~m}$ in CZ), grabens, individual isolated elevations and gently undulated plateaus. The geological fundament is constituted by Precambrian gneisses which are penetrated by boles of Šumava's Variscan granite pluton. Quaternary mantles include fluvial and deluviofluvial deposits of valley beds and rock detrite in lower parts of slopes lining the valley beds and shallow saddles. Quaternary rock is usually covered with layers of Holocene peat of differing thickness. The climate is cold with mean January temperatures TI. $=-3$ to $-5{ }^{\circ} \mathrm{C}$ and mean July temperatures TVII. $=14-16{ }^{\circ} \mathrm{C}$. Mean annual precipitation is sa $=$ 1,000-1,200 $\mathrm{mm}$. Potential vegetation belongs to the 6 (spruce-beech) -8 th (spruce) forest vegetation zones.

In old times a trade path ran through the forested border area, connecting Bohemia in the north and Bavaria in the south and enabling the exchange of goods (north received salt, wine and other produce, while south received honey, fabrics and cattle). This branch of the so-called "Salt Path" (sometimes also called the Golden Path) connected in Middle Ages the town of Passau with Prachatice and Vimperk. Both settlements Philipsreuth and Strážný were founded in 17th century and worked as border stations (Havensath 1995). These two villages with streets were built in valleys while the villages of lumberjacks and crofters (Vorder-, Mittel- and Hinterfirmiansreuth on the German side and Silnice on the Czech side) were scattered higher on hillsides (Fig. 2). The entire border area of interest has traditionally focused on forestry, pasturage and humble farming, while trade, tourist industry and winter sports are actively developing. The mosaic of land use is traditionally comple-

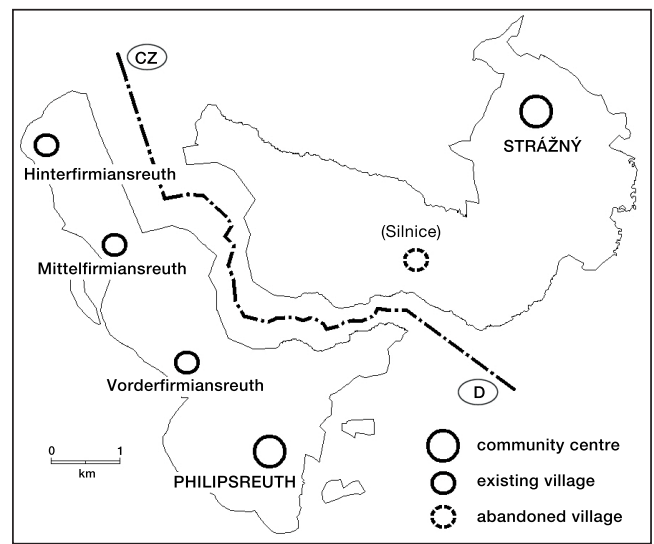

Fig. 2 - Settlements of both neighboring municipalities at the Czech-Bavarian border (CZ Czechia, D - Germany) 


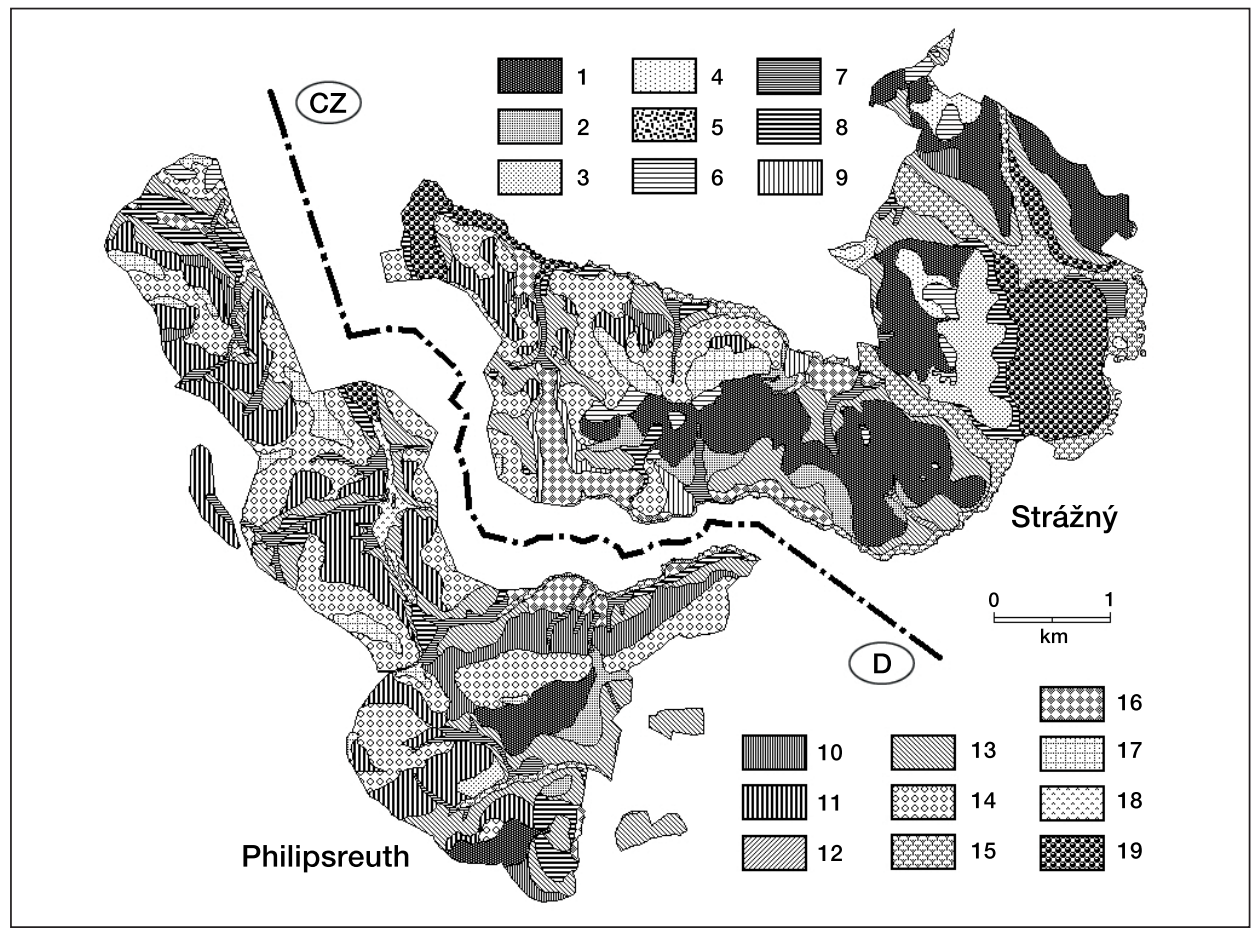

Fig. 3 - Types of natural landscape units of the study area representing classes of the natural environment for the land use formation and development (legend see Table 1)

[\%]

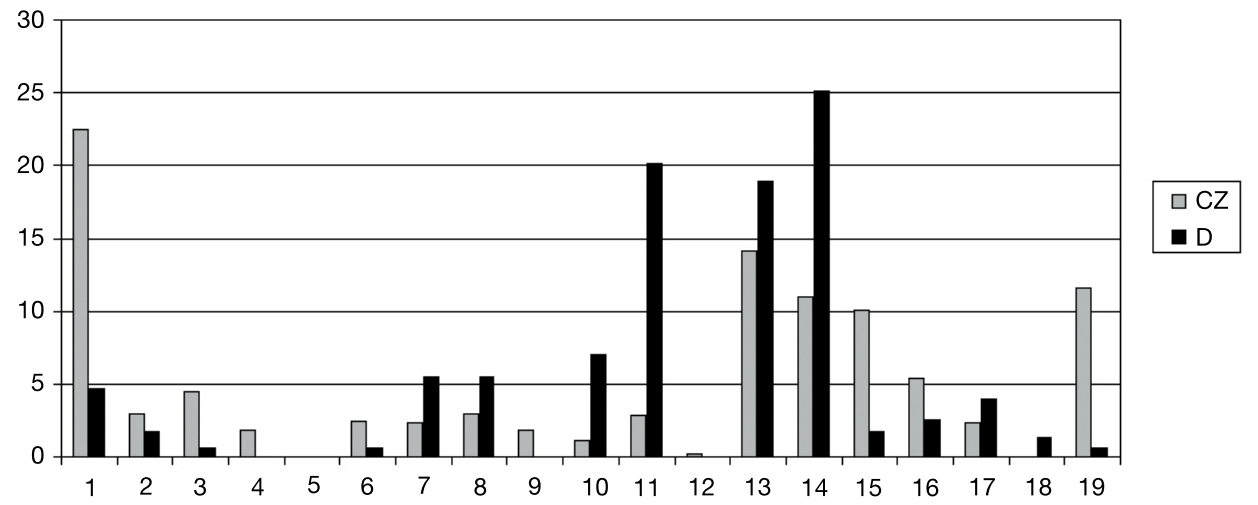

Fig. 4 - Relative presence of natural unit classes in both border municipalities (in \% of total area of each municipality)

mented with small gardens and scattered or concentrated built-up areas, with small water bodies in places.

Following a logical integration of analytical maps of natural landscape components, which drew either on diverse archive sources or our own field research, we have determined a network of homogenous natural landscape 
Tab. 1 - Parameters of identified types of natural landscape unit

\begin{tabular}{|c|c|c|c|c|c|c|}
\hline $\begin{array}{l}\text { Class } \\
\text { No. }\end{array}$ & Climate & $\begin{array}{l}\text { Forest } \\
\text { stage }\end{array}$ & Geology & Soil type & Soil mechanism & Humidity \\
\hline 1 & cold & 6 & crystalline & dystric cambisols & loamy-sandy & normal \\
\hline 2 & cold & 6 & crystalline & gleyic cambisols & $\begin{array}{l}\text { sandy-loamy to } \\
\text { clayic-loamy }\end{array}$ & fresh \\
\hline 3 & cold & 6 & crystalline & eutric cambisols & $\begin{array}{l}\text { sandy-loamy to } \\
\text { loamy-sandy }\end{array}$ & normal \\
\hline 4 & cold & 6 & crystalline & podzols & loamy-sandy & normal \\
\hline 5 & cold & 6 & peat & organosols & biodetritic & wet \\
\hline 6 & cold & 6 & crystalline & rankers & stony & dry \\
\hline 7 & very cold & 7 & $\begin{array}{l}\text { (deluvio)fluvial } \\
\text { deposits }\end{array}$ & fluvisols & $\begin{array}{l}\text { loamy-clayic to } \\
\text { clayic }\end{array}$ & humid \\
\hline 8 & very cold & 7 & slope deposits & gleysols & $\begin{array}{l}\text { loamy-clayic to } \\
\text { clayic }\end{array}$ & humid \\
\hline 9 & very cold & 7 & peat & gleysols & biodetritická & humid \\
\hline 10 & very cold & 7 & crystalline & dystric cambisols & loamy-sandy & normal \\
\hline 11 & very cold & 7 & crystalline & eutric cambisols & $\begin{array}{l}\text { sandy-loamy to } \\
\text { loamy-sandy }\end{array}$ & normal \\
\hline 12 & very cold & 7 & $\begin{array}{l}\text { (deluvio)fluvial } \\
\text { deposits }\end{array}$ & pseudogleysols & $\begin{array}{l}\text { clayic-loamy to } \\
\text { loamy-clayic }\end{array}$ & moist \\
\hline 13 & very cold & 7 & slope deposits & pseudogleysols & $\begin{array}{l}\text { clayic-loamy to } \\
\text { loamy-clayic }\end{array}$ & moist \\
\hline 14 & very cold & 7 & crystalline & podzols & loamy-sandy & normal \\
\hline 15 & very cold & 7 & $\begin{array}{l}\text { (deluvio)fluvial } \\
\text { deposits }\end{array}$ & organosols & biodetritic & wet \\
\hline 16 & very cold & 7 & peat & organosols & biodetritic & wet \\
\hline 17 & very cold & 7 & crystalline & rankers & stony & dry \\
\hline 18 & cool & 8 & $\begin{array}{l}\text { (deluvio)fluvial } \\
\text { deposits }\end{array}$ & organosols & biodetritic & wet \\
\hline 19 & cool & 8 & peat & organosols & biodetritic & wet \\
\hline
\end{tabular}

Note: forest stages: 6 - spruce-beech, 7 - beech-spruce, 8 - spruce

units - natural geosystems on the microchoric level of geographic division of landscape. The process of integration consists of putting transparent analytical maps in analog form with the working scale of 1:10,000 on top of each other and of outlining common areas of several parameters described by a vector, whose co-ordinates were values of variables subtracted from individual analytical maps for a given area. Logical combinations of variables which occur in nature were left in, while illogical combinations were individually corrected by replacing the "faulty" variable. The result of such a process was a map of natural landscape which was scanned, georeferenced and vectorised into a map with added database of several dimensions. For further interpretation we thus prepared a digital landscape map distinguishing 19 types of geosystems - natural landscape units on the topical level (Fig. 3, Tab. 1).

Geosystems are landscape units which are internally homogenous on a given level of resolution and are described in this case by the following natural 
parametres: geological structure, soil and vegetation cover, climate, vegetation and humidity conditions. These conditions clearly influence the choice and distribution of individual forms of land use. For comparison of present of all the natural geosystems on the both sides of the border, the geostatistical counting was done and results presented in figures (Fig. 4).

Historical cartographic data on land use come from national archives of historical maps and from land registers from both countries. These analog materials were also digitized, georeferenced and vectorized. Situation in 2002 was mapped over a digital orthophotomap which was thoroughly and systematically interpreted in the field. Some additions were made on the Czech side in 2007. Differing quality and thematic resolution of historical land use maps are reflected in the extent of references (1829-1840: 7 items, 1935-1938: 8 items, 2002-2007: 21 items). In order to secure a mutual comparability of maps it was necessary to qualitatively generalize the content of more recent data to the level of the oldest map. However, resolution of added databases was not affected. The census data from both sides of the bordes were presented and used for the explanation of some land use changes.

\section{Land use and population changes in border municipalities}

At the beginning of the monitored period, i.e. in the first half of the 19th century (Fig. 5), the municipalities of Philipsreuth (1829) and Strážný (1840) constituted centers of deforested ecumenes. The degree of deforestation was significantly higher in the Czech part owing to its slightly lower and warmer position in a less dissected topography. Other German villages were centers of smaller deforested areas. Former village Silnice, which covered virtually the entire length of the municipality's cadastre of approximately $5 \mathrm{~km}$, showed asymmetric and scattered use of land with prevalent meadows and pastures and a significant percentage of arable land. Similar situation can be detected in the cadastre of Strážný. Oat and rye represented traditional crops, potatoes were added in the end of 18th century (Gion 1997). A part of larger cattle herd was driven every year from Czech side to Bavarian markets. Larger forest units were preserved in the highest altitudes with steep hillsides in both areas, in the German part also in waterlogged flat drainage divides.

We can say that the degree of landscape transformation through the human activities was higher on the Czech side where more numerous local population lived predominantly in farmhouses with meadows and fields and felled timber for their own use. Strážný was granted the market place in 1844. At that time in 72 houses lived about 800 inhabitants. The school operated here since 1781. The less populated settlements on the German side (app. 500 inhabitants in 1840 , school since 1851) did not develop such a pressure on extending the area of arable land and pastures (Dorn 1997). From this we can deduce that wood cutting and timber trade sufficed to support most of the local inhabitants and cattle raising and farming were only of complementing nature. An important part of family incomes in the both municipalities was represented by home craft (wooden products) and employment in sawmills.

In the years preceding World War 2 (1935-1938) the German part of the interest area was characterized by decreased human impact on landscape 


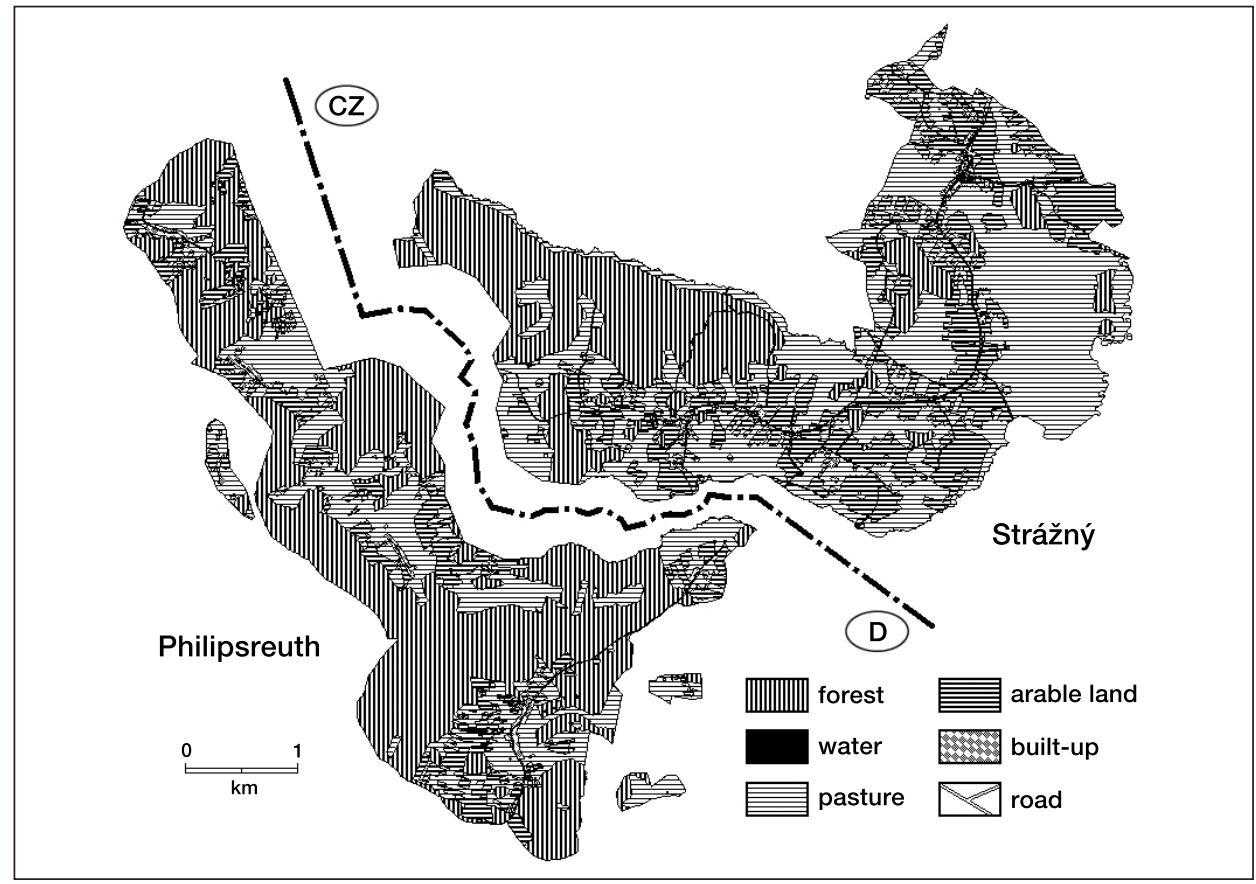

Fig. 5 - Land use of the bordering municipalities in 1829-1840

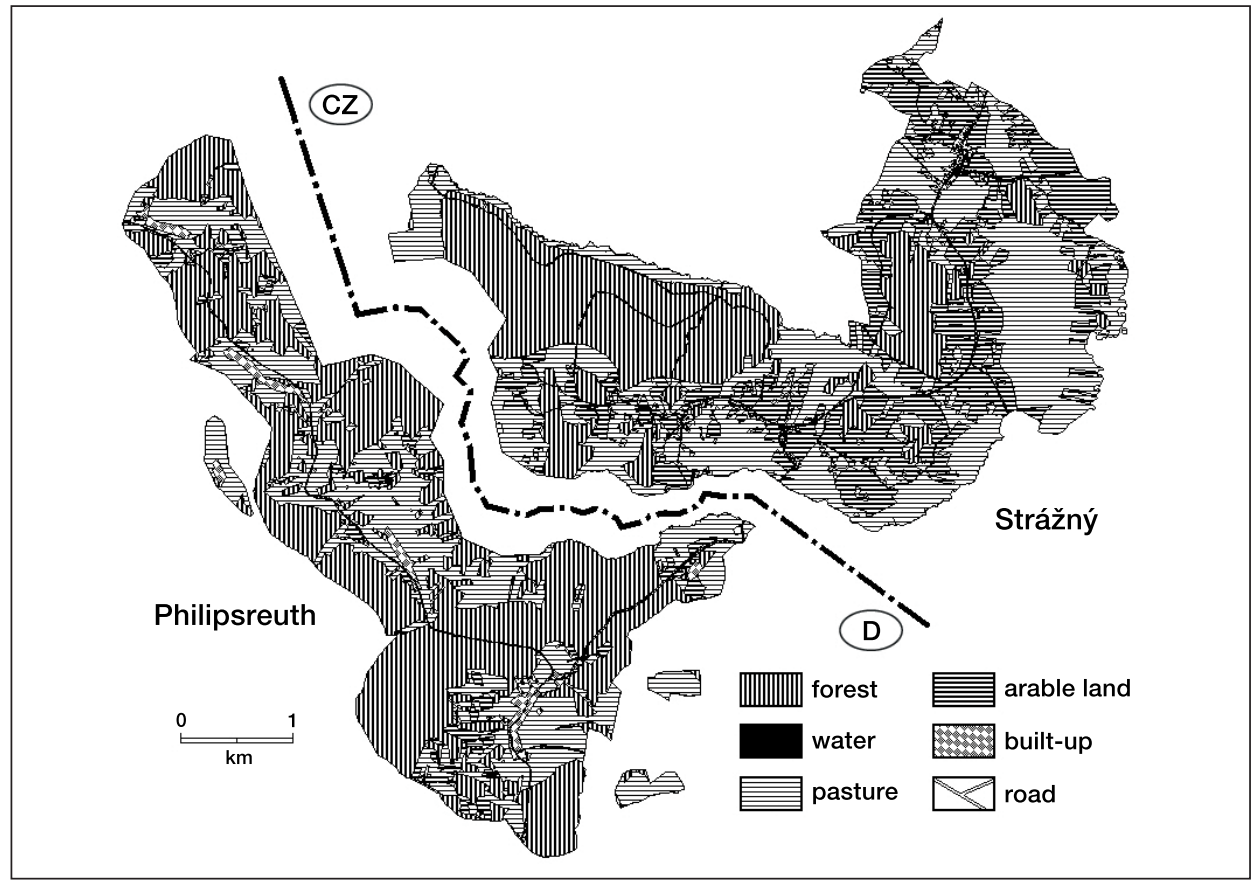

Fig. 6 - Land use of the bordering municipalities in 1935-1938 


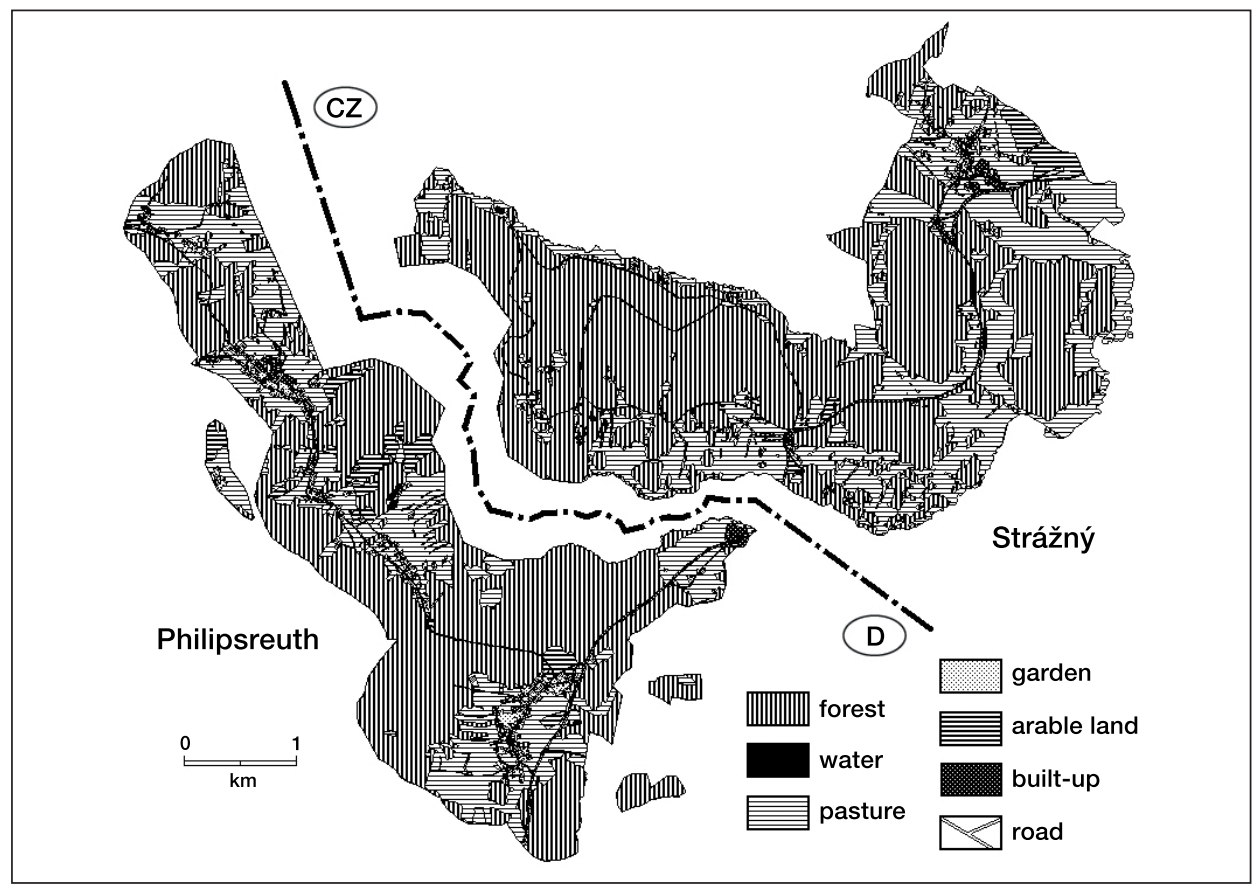

Fig. 7 - Land use of the bordering municipalities in 2002-2007

(Fig. 6) because of growing peripheral status of the municipality with very difficult motorized access. Forested areas were stabilized and showed minimum changes when compared to the previous period. Development increased rapidly, catering for the housing and economic needs of the contemporary number of inhabitants. By the 1930s human impact on landscape in the Czech part had increased, as the extended area of farmland shows. That time Strážný (app. 2,200 inhab.) served as the cross-border shopping place for the population (app. 650 inhab.) of Philipsreuth (Praxl 1997). In general terms, land use became more contrasted, as the extent of ploughed up areas and built-up areas increased but simultaneously forest areas increased, particularly in higher altitudes and on steeper hillsides, usually replacing pastures. The green land was reduced in favour of arable land.

Until the fall of the "iron curtain" on the Czech-Bavarian border in 1989, both the municipalities survived different evolution regardless their similar geographic position "on the ends of the Western and Eastern worlds". While the West-German federal government supported the Philipsreuth municipality by various development programs to keep active population here, the post-war and especially the communist Czechoslovak regime developed predominantly the military and later the transit function of the Strážný municipality. By 2002-2007 both areas had witnessed an increase of forest land (Fig. 7). In real terms, the Czech side had doubled the area of forest land, in particular in the cadastre of the former village of Silnice which was situated in the military border area for a long time. The present configuration of forested areas resembles the situation in the German part, where predominantly elevations have been 
forested - hilltops and high and steep hillsides. Both areas have experienced loss of meadows, mostly through forestation. This loss was partly compensated for by grassing arable land. The percentage of arable land in both areas has dropped almost to zero. Even the remaining plots of arable land are used for growing fodder crops. Despite the elimination of the municipality Silnice, and drop of Strážný population from 2,700 to 250 after resettlement of German population on June 5, 1946, the Czech side is characterized by a slight area increase of built-up areas (Czech Germans were expelled from some German political viewpoints.). Their total is bigger than before World War 2. However, a substantial part of growing development is accounted for extensive trade (shopping halls, kiosks), development of gambling houses (casinos), and erotic tourism, accommodation and facilities for winter sports. Immediately in 1946, the population number of Philipsreuth has grown up from app 650 to 1,000 as a part of Czech Germans was settled here. Also the development on the German side was later connected to growing tourist industry, in particular winter sports. Its growth cannot be feasibly demonstrated, as only data on the residential areas of settlements as whole entities are available for more distant past, while at present the relevant data cover directly the built-up areas.

The questionnaire field research (Hoffarth 2005) has been carried out in both of municipalities in 2004 to identify the relationship of local population to their home place (app. 200 persons on each side of the border was questionnaired). While $60 \%$ of Philipsreuth population (less than 800) was born in the municipality, app. $80 \%$ of Strážný population (app. 300) are immigrants. App. 95\% Philipsreuth inhabitants live in own dwellings, in Strážný the same makes only less than $30 \%$ and app. $65 \%$ of inhabitants live in rented houses, flats and rooms. That is why the population on the German side is closely connected with its living places (more than $90 \%$ of inhabitants do not think about move to other place). About 25\% of Czechs and numerous Vietnamese merchants on the Czech side think about other place for living.

\section{Identification and assessment of land use development trends}

Land use changes represent traditional subject of geographic research for long time. The research depth and result understanding depend on the level of accuracy of identified changes location (Fig. 8). The simplies way is the verbal location in time. More precious one is statistical description of land use change in the reference area, usually municipality area, in relative or absolute values. More detail change location is given by geographic co-ordinates as a geometric location. This way, the chronological sequence of land utilizing can be detected in every place, or in opposite to identify localities without land use changes during the time period investigated. As seen in the Fig. 9, the land utilizing, and especially forested areas are very stable in Philipsreuth municipality. The Czech part of the study territory is much more dynamic from the viewpoint of land utilizing. This phenomenon is probably related with much higher population number until World War 2 and post-war area transformation into the military border zone connected with extreme population number decrease.

The identification of development trends of land use issues from the assessment of area dominance of individual forms of land use in the area as 


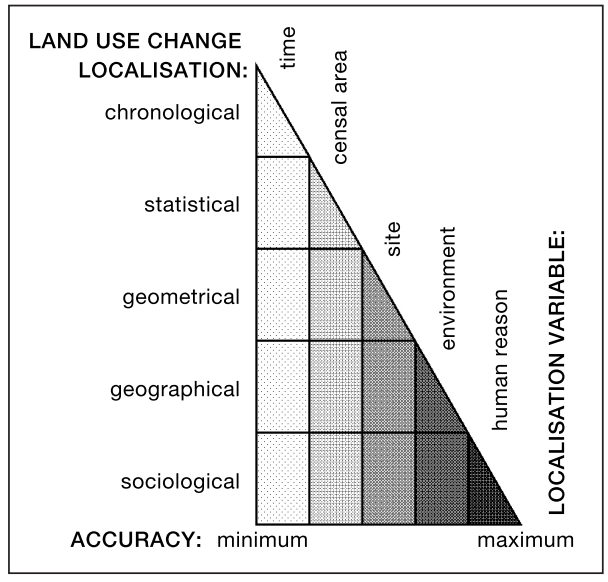

Fig. 8 - Accuracy levels of land use changes location

a whole, in its individual national parts and against the background of individual groups of natural landscape unit types as the natural (geographical) environment. Geographical location of land use change helps to explain previous decision of social driving forces. Using GIS technology, it is possible locate land use change into its environment. The following sociological location of land use changes needs very detail knowledge about ownership area features what is very difficult to identify back to the history. Basic spatial analyses were carried out with the help of SW GIS ArcView tools with the extension Spatial Analyst. Acquired data were statistically evaluated in the application Microsoft Excel and classification procedures were based on software package Unistat 5.5 for Excel.

The outcome of the geostatistic data processing was a number of comparative tables, graphs and development curves. A glimpse of the frequency distribution of the changes in area dominance of forests, meadows, arable land and built-up areas (the most important and most frequent land use forms giving

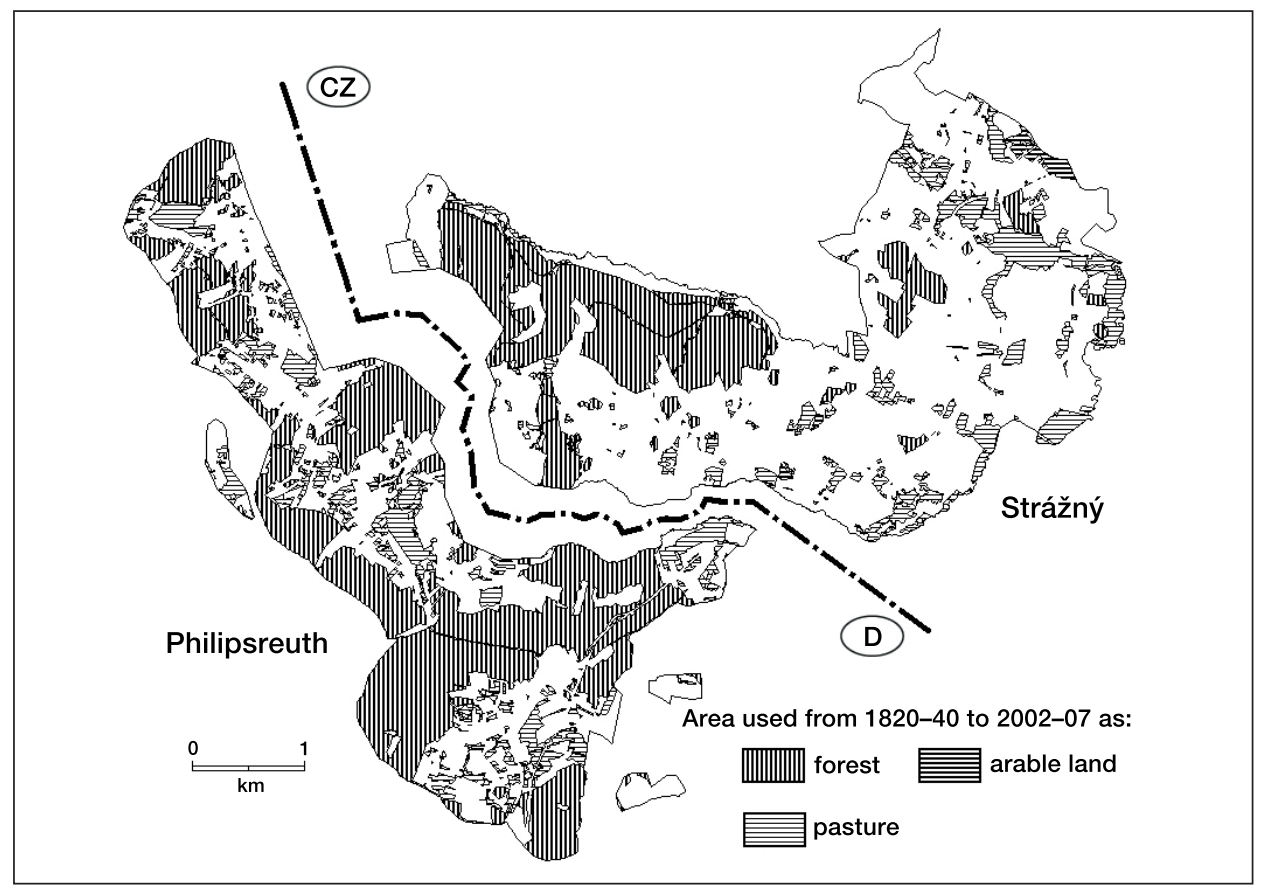

Fig. 9 - Areas without land use changes during the study period 


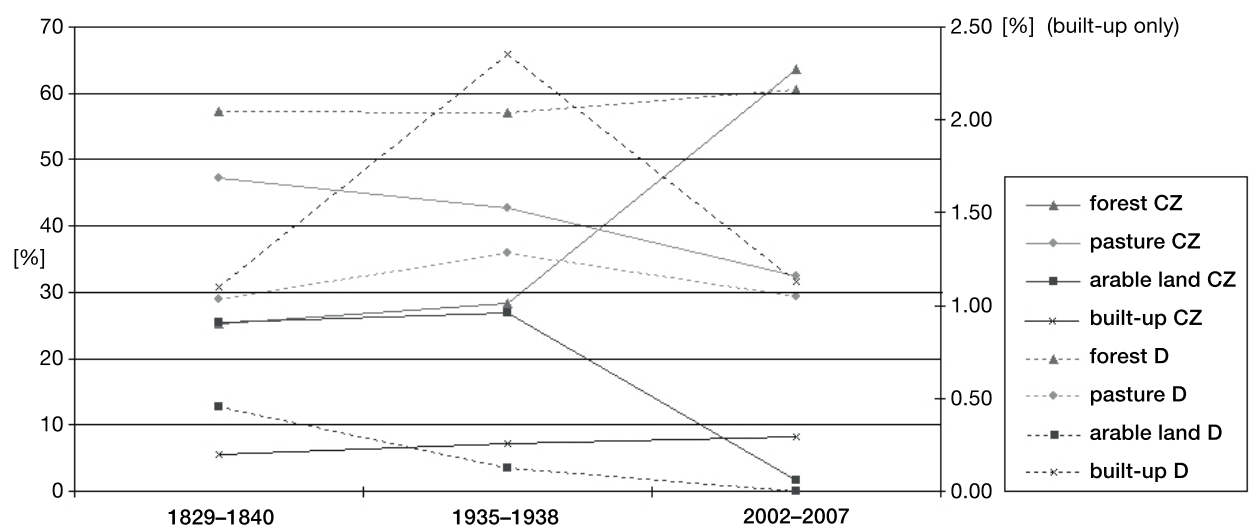

Fig. 10 - Development of dominant land use forms in both border municipalities (in \% of area of each municipality)

the landscape view to the area) in the analyzed periods in the both entire areas of Strážný and Philipsreuth municipalities (Fig. 10) implies that despite similar natural conditions the points of departure for land use in the first half of the 19th century were different, owing to different economic orientation and different degree of economic specialization of the inhabitants of the border settlements. As a result of historical twists of prewar years, land use in the two national parts of the area did not approximate despite the fact that there were little differences in the population's ethnic composition (the percentage of Czechs among the inhabitants of Strážný and Silnice was negligible). It follows that different economic climate on either side of the border played the key role. Despite the fact that most people made their living in forests, this type of jobs did not sustain them and other, mostly agricultural, activities were a necessity. On the German side farming probably played only a minor role and continuously lost its importance. Following the Munich conference the areas on both sides of the border were joined in a higher administration unit but remained economically different. The manifestation of such differences was a different structure of land use as a result of differentiated impact on land, which among other things reflected different standards of living.

The period after World War 2 witnessed a radical change in political and economic situation, particularly on the Czech side. Following the resettlement of most German inhabitants a border zone was established which considerably limited the area's economic use and even settlement. The municipality Silnice practically disappeared. Old farmhouses scattered along the border were deserted and only customs buildings and the border crossing remained from the original village. Even these buildings were used occasionally when needed for the guarding of state border. Also in Strážný a number of farmhouses were deserted. Population decrease and political obstacles resulted in a drop in land demand, which in turn brought about gradual natural succession and eventually forests were planted on the deserted farmland (both arable land and meadows). The German side experienced a less obvious population reflux in favour of inland and also the decrease in land demand was less pronounced, among other things owing to a formerly weaker orientation towards farming 

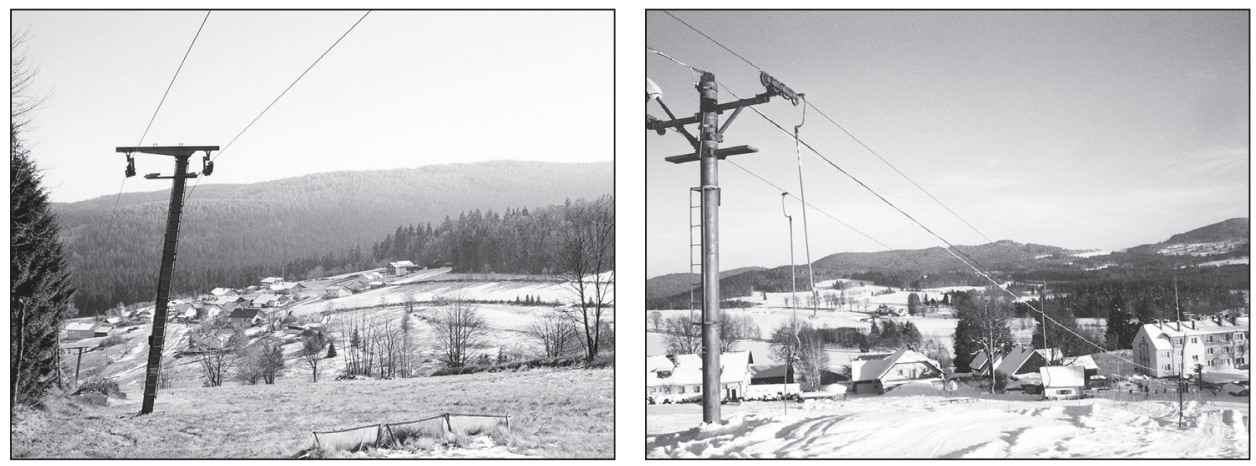

Fig. 11 - Visual landscape convergence is given for instance by orientation of recreation and winter sports (left - Philipsreuth, right Strážný)

production. Restructuring of employment stressed the recreational function of all the settlements, Mittelfirmiansreuth in particular, which developed into a winter sports resort with corresponding facilities and infrastructure. A similar development, especially after 1989, can be traced in Strážný where a network of tourist and entertainment services has been built, including extensive "stall trade" activities. The area of arable land in the interest area is negligible on both sides of the border today. Apart from the residential area of Strážný the entire area on the Czech side is protected as a part of the National Park Šumava and east of the international road connecting Passau and Vimperk as a part of the Protected Landscape Area Šumava. The German side does not have a similar status of land protection.

It is a remarkable to ascertain that the development on one side was distinctly different and independent of the development in its counterpart across the border at least during the post-war period until 1990. The area has seen a physiognomic (visual) land convergence (Fig. 11), in particular when it comes to the distribution of forest units, meadows and pastures on either side of the border within the analogical types of natural environment and position. Statistical data about the presence of these main and physiognomic land use forms (Fig. 12) served for further area classification. These histograms show the large difference in the land use of individual natural landscape unit types in the past and the high level of similarity at the present. For details, two examples can be used. This converge effect has also seen the development of a similar structure of land use in two selected natural landscape unit types represented sufficiently in both national areas (Fig. 13, see groups No. 13 - "moist units", No. 14 - "podzolized units" abundant on both sides of the border). However, landscape types represented plentifully in both areas in an extremely different share differ in their present pattern of use.

It follows that if large parts of both areas show same or similar natural conditions, their structure of use is also corresponding. On the contrary, special types of natural environment without a corresponding equivalent abroad tend to have a different structure of use. A hypothesis comes along to explain these facts: along both sides of the border a "generally rational" structure of land use is being formed, respecting (today and in the recent past) the marginalization of the area, its gradual depopulation, extensification of agriculture, while 


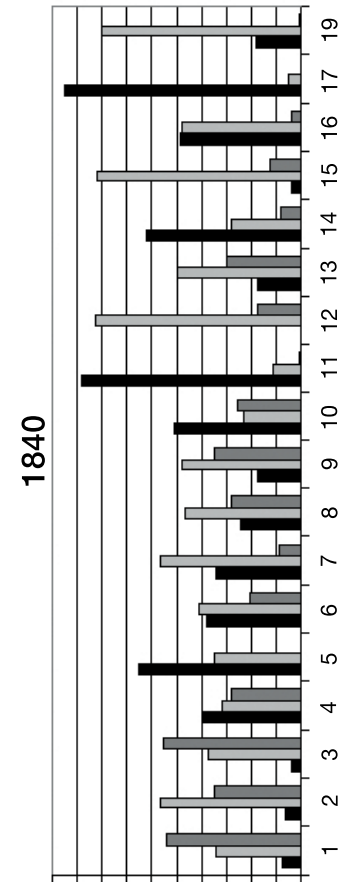

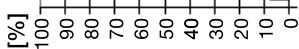

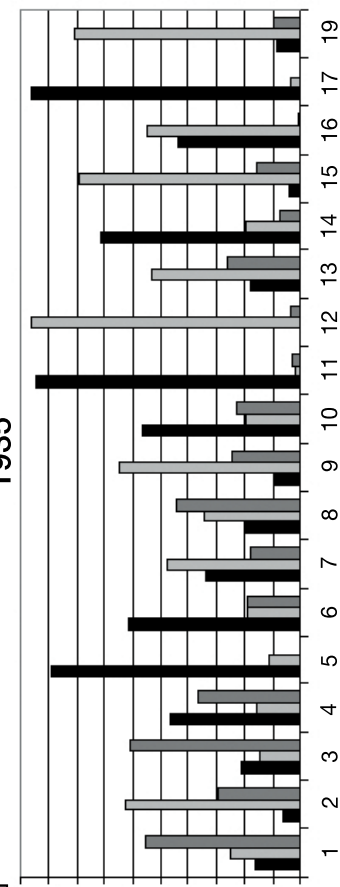

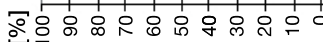

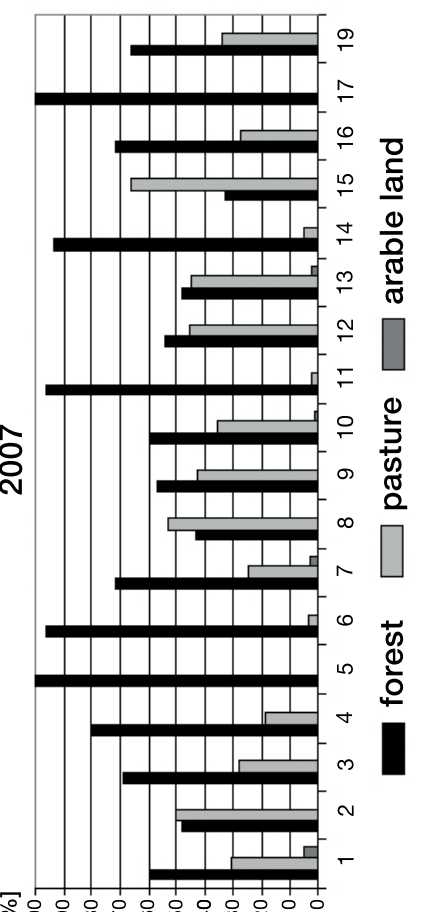

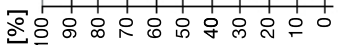

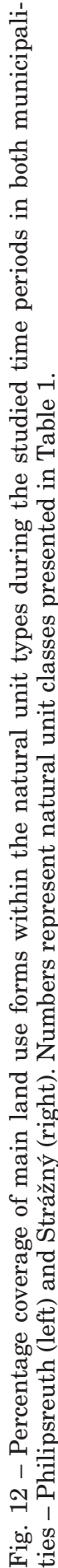

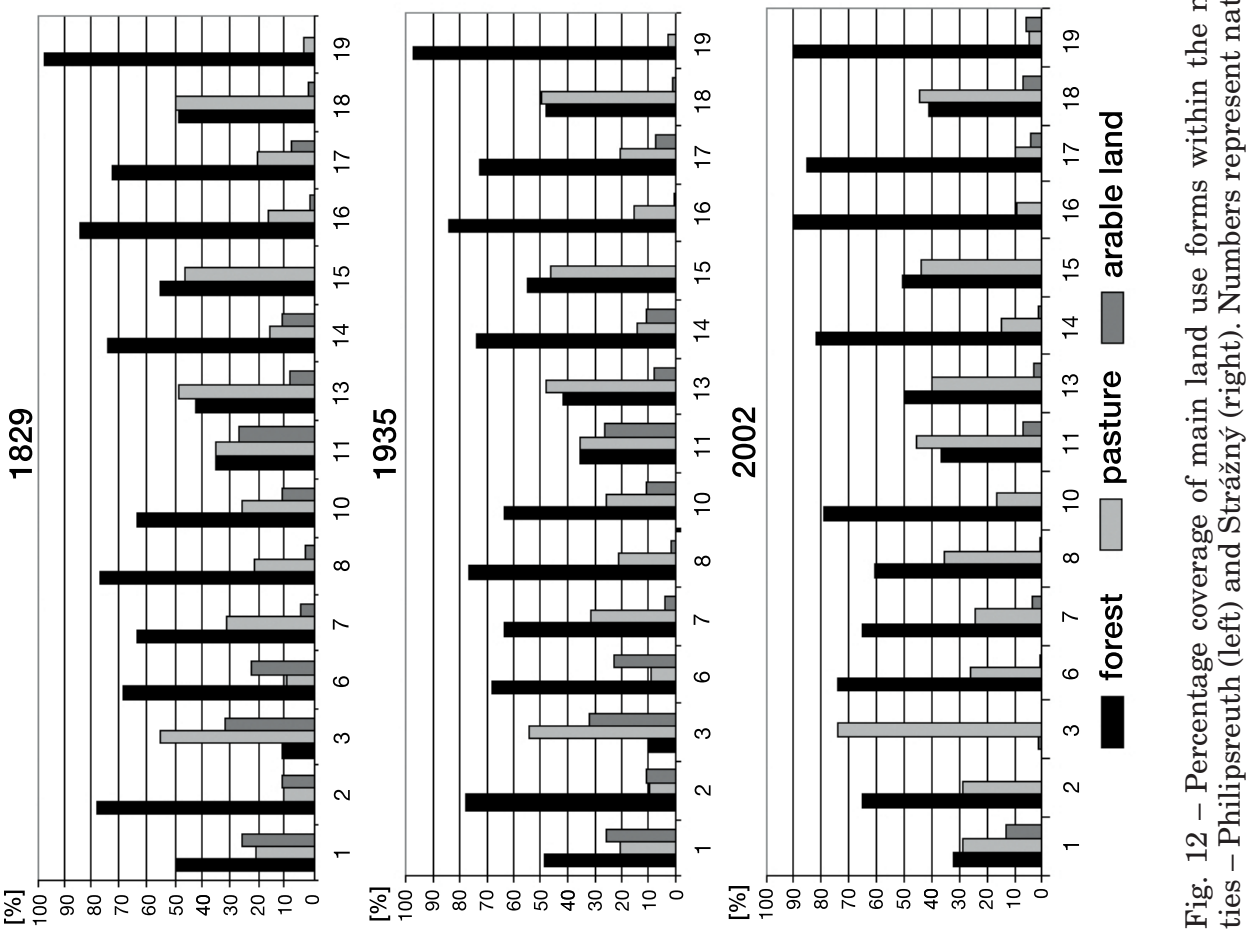



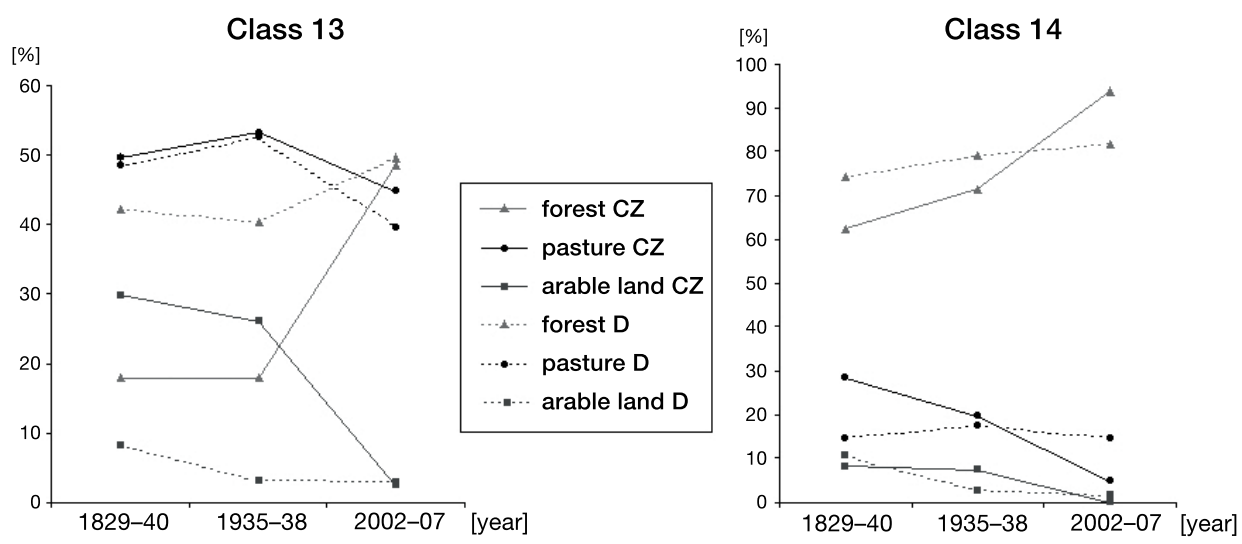

Fig. 13 - Similarity of land use development trends in two abundant natural landscape unit types (classes) in both border municipalities leads to visual and functional unit convergence (in \% of total class area)

strengthening its recreational role regardless the prevalent socio-economic system and standard of living.

Software GIS ArcView tools enables us to create applicable statistical background documentation for more detailed analyses and data syntheses. Each type of a natural landscape unit, separately for the Czech and the German part of the area, has been described by an appropriate percentage of individual forms of land use in all three analyzed periods. Owing to the fact that a decisive part of all the units was always constituted by forests, meadows and possibly arable land, these dominant physiognomic units of cultural landscape were selected for further assessment. Each group of types of natural landscape units both in the Czech and German parts was described by a nine-digit vector whose co-ordinates presented the percentage of forests, meadows and arable land in the years 1829-1840, 1935-1938 and 2002.

The actual subject of unit classification were series of the so-called indexes of change (Ic), calculated for pairs of subsequent terms of registered percentages for individual forms of land use. The following formula (1) was used for each group of natural landscape units:

$$
I_{c}=(B-A) / \text { average }(A, B)
$$

$B$ stands for the percentage of a given form of land use within the total area of a selected group of a natural landscape unit in the following term

$A$ stands for the percentage of a given form of land use within the total area of a selected group of a natural landscape unit in the term preceding term B.

This way we "relativised" differing absolute area coverage of individual groups of natural landscape units and trace upward/downward development stages of a given form of land use. The resulting six indexes of change for each group of natural landscape units separately for each national area were classified with the help of cluster analysis in Unistat 5.5 for Excel. Within a group of principally similar results of clustering - dendrograms (tree-diagrams) of similarity - we can illustrate an uncontrolled classification in the result of the implemented method of "Furthest Neighbor" (Fig. 14). 


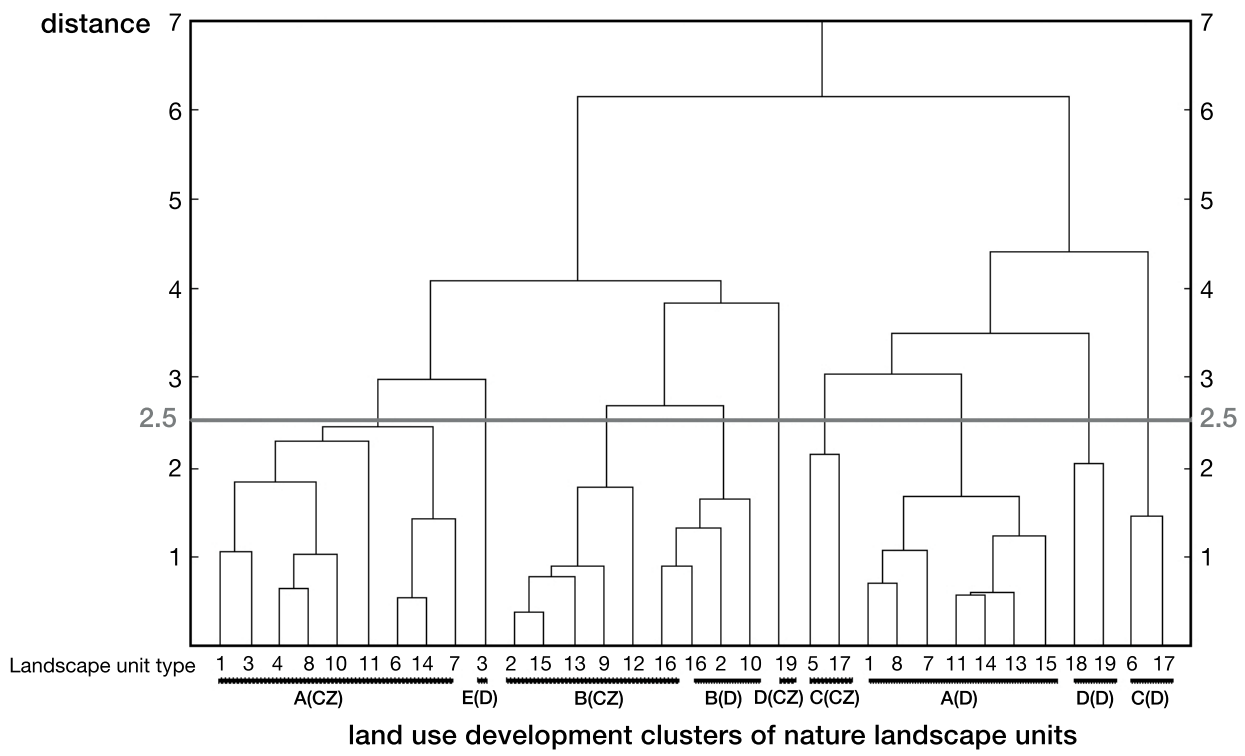

Fig. 14 - Classification of natural landscape units from the viewpoint of land use development trends in both municipalities (D - Philipsreuth, CZ - Strážný) using cluster analysis

Through iteration we gradually formed similarity groups of landscape units which have undergone a similar development of land use. On the similarity level (distance) $\mathrm{Hp}=2.5$ was set STOP to clustering and as a result 4 groups of units were established in the Czech part and 5 groups of landscape units in the German part, all with similar development. Based on these results, pairs of groups CZ-D were established: A-A, B-B, C-C, D-D according to their natural landscape units. Fifth group $\mathrm{E}$ in Germany does not have analogy on the Czech side. However, it is negligibly small and thus was not subject to further analyses.

It transpired that in order to achieve a similar target effect, i.e. highly similar present use, the individual groups of natural landscape units separately in the Czech and German parts "chose" either entirely different or on the contrary the same strategies.

The group of natural landscape units of type A (see Fig. 15), which includes predominantly areas of valley bottoms and stony hillsides on both sides of the border, is characterized by an antithetic development connected with a dramatic loss of arable land and increase of forest on the Czech side, while on the German side the changes of land use are negligible. Despite this the structures of land use on both sides of the border converge. Group B with similar representation of units which considerably differ in humidity is characterized by a gradual development on the German side and a similar but faster development on the Czech side. However, the structure of units use remains radically different. The German side is predominantly reforested, the Czech side shows a balance between forests and meadows. Units of type $\mathrm{C}$ include extreme stony (in parts wet) units and demonstrate an identical development over the entire period of time on both sides of the border, showing a slight 

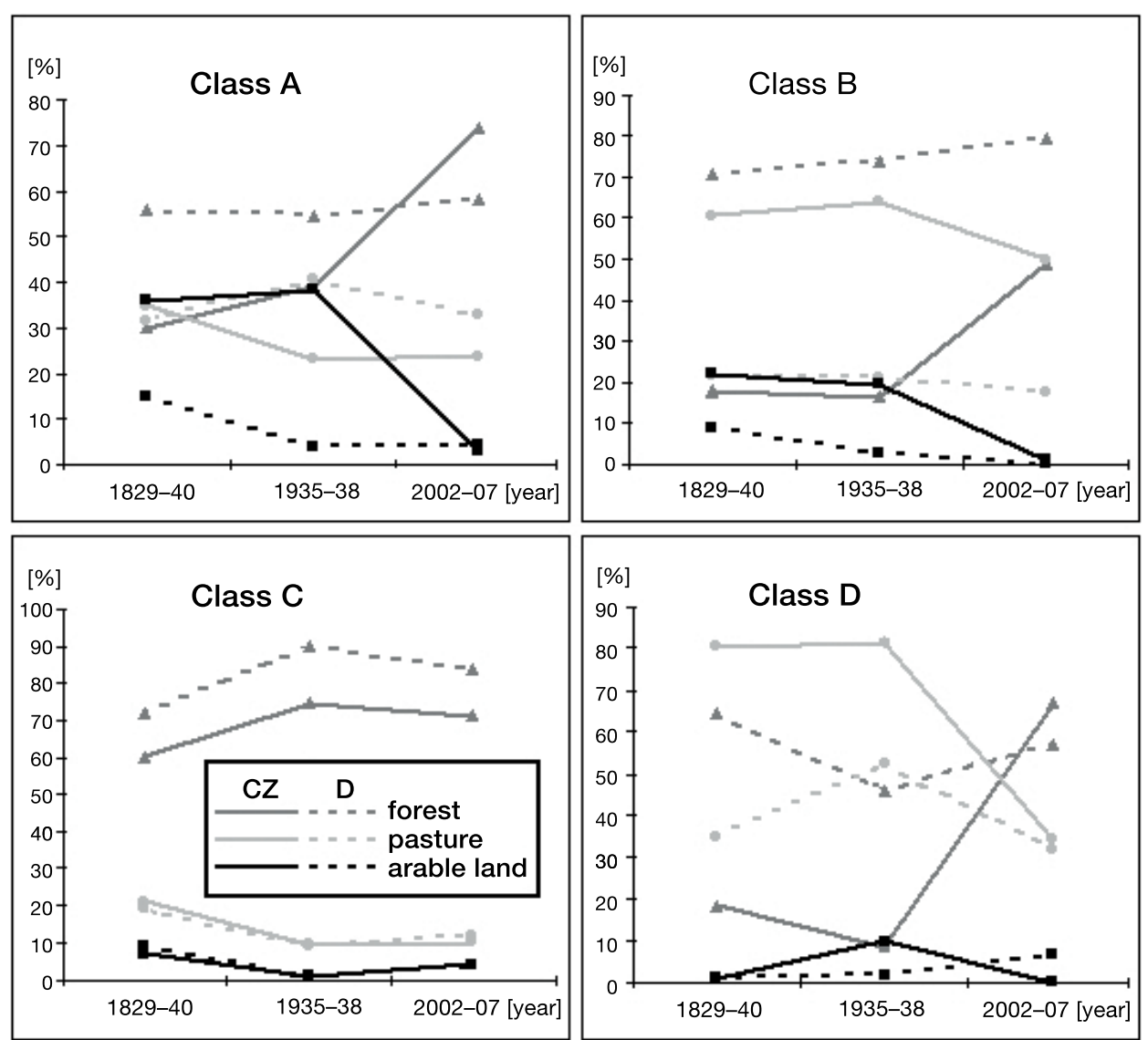

Fig. 15 - Typical schemes of the land use development of four (of total 5) representing dominant natural landscape unit classes. Class members shown in Figure 14. The convergence trends are strictly dominant clearly in A, C and D class, partially in class B (values shown in graphs represent \% of total class area).

fluctuation in the percentage of monitored forms of land use. Dramatic and entirely different changes characterize the group of units $\mathrm{D}$ on both sides of the border. However, these lead to an almost perfect convergence of the present land use where forests slightly prevail over meadows. Group E exists only on the German side and shows loss of forests which are constantly scarce, while dominant meadows gain dominance and arable land is entirely eliminated.

Generally speaking, both the entire area and its individual types of natural landscape units (except group B) are characterized by strong use convergence (Fig. 16). However, strategies for achieving this convergence differ: from chaotic changes in the past (D) to a more extreme concept of trends on the German side (A) or a completely analogical development (C). 


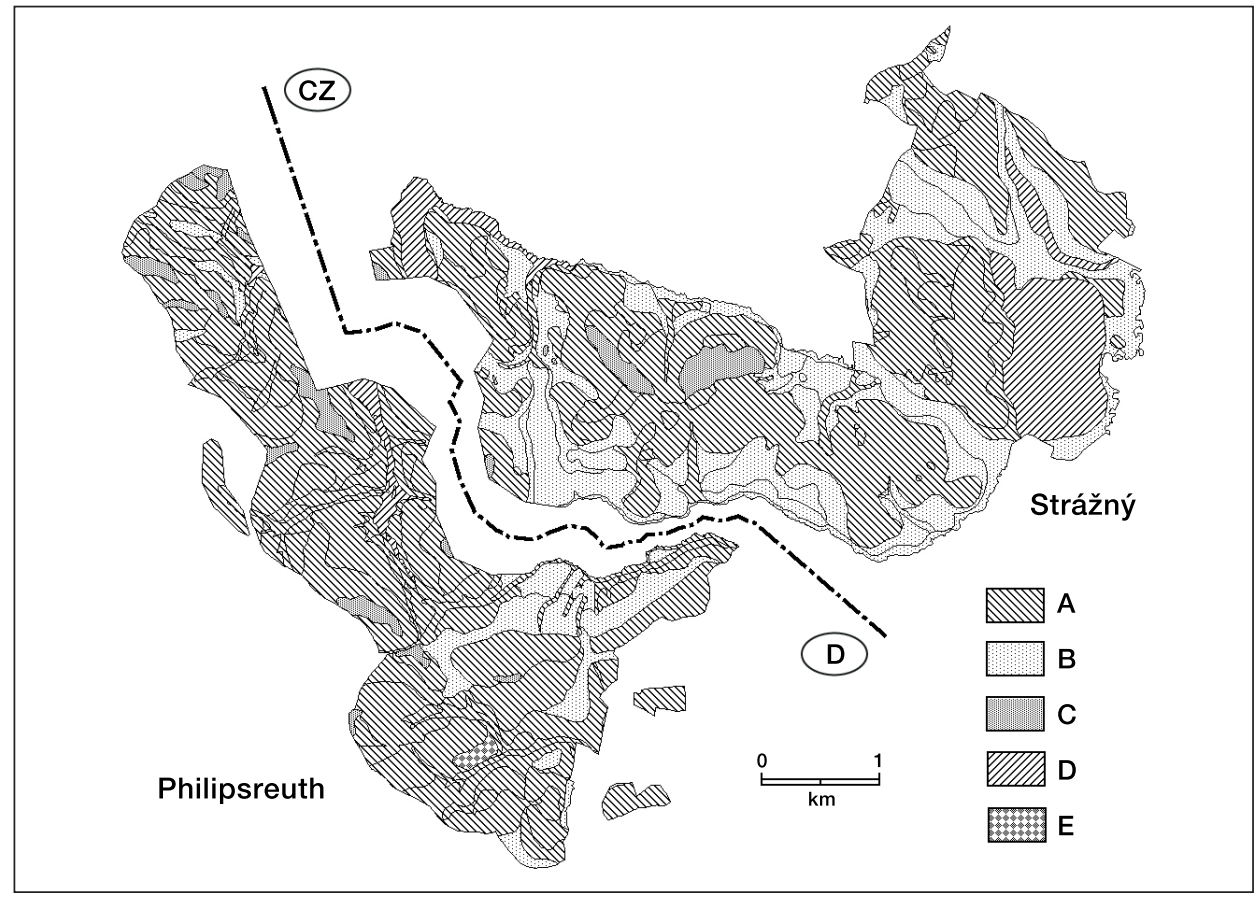

Fig. 16 - Territorial distribution of natural landscape unit classes depicted by land use development trends in the last two centuries (A-D, development trends as seen in Fig. 15, trend $\mathrm{E}$ in one example only)

\section{Discussion}

Our finds render an interesting experience by partially opposing the opinion that economic system (of course alongside natural conditions) determines the structure of land use. However, the data obtained from the interest area seem to prove that the tendency towards a "more rational" organization of a functional landscape mosaic is generally consistent and that population density and partly standard of living, or "economic climate", play a dominant role. Such process could be accelerated on the side by the area position within the Šumava National Park and Landscape Protected Area boundaries. Despite the fact that the area lies in borderland we can assume that a similar convergence of functional structure (and appearance) can occur also in inland regions with similar natural conditions. Inland natural units experience a different economic pressure and thus we cannot transfer the acquired finds mechanically to such areas. However, even in these regions an integrated nature demonstration, population density and general economic climate should demonstrate analogical pattern of land use. This can lead to the demise of typical landscapes, in particular of landscapes which were originally ethnographically and culturally different. In antithesis to the general tendency of European Union to secure the sufficient standard of living for all inhabitants, the creation of the similar economic climate can prove to be contrary to the European efforts to 
maintain the high diversity of cultures and consequently cultural landscapes. It appears that this subject will require more extensive research. Should the above described processes be confirmed, we should start considering the tools which would enable us to maintain cultural landscape diversity in such a way biological diversity is maintained.

\section{References:}

BABU, R. S. (2002): Environmental degradation and its impact on land use/land cover changes in agriculturally developed region sof India. In: Bičík, I., Chromý, P., Jančák, V., Janů, H. (eds.): Land use/land cover changes in the period of globalization. Proceedings of the IGU-LUCC International Conference Prague 2001, Charles University, Prague, pp. 67-74.

BALÁZS, K., ÁNGYÁN, J., PODMANICZKY, L. (2002): Evaluation agricultural potentials and environmental sensitivity for sustainable land use planning. In: Bičík, I., Chromý, P., Jančák, V., Janů, H. (eds.): Land use/land cover changes in the period of globalization. Proceedings of the IGU-LUCC International Conference Prague 2001, Charles University, Prague, pp. 88-94.

BALEJ, M (2007): Hodnocení vývoje horizontální struktury krajiny vybraných modelových území severozápadních Čech ve 2. polovině 20. století. PhD Thesis, UJEP, Ústí nad Labem, $246 \mathrm{pp}$.

BIČÍK, I., JELEČEK, L. (2003): Long Term Research of LUCC in Czechia 1845-2000. In: Jeleček, L. (ed.): Dealing with Diversity. Proceedings 2nd International Conference of the European Society for Environmental History Prague 2003, Charles University, Prague, pp. 224-231.

CHROMÝ, P. (2003): Memory of Landscape and Regional Identity: Potential for Regional Development of Peripheral Regions. In: Jeleček, L. (ed.): Dealing with Diversity. Proceedings 2nd International Conference of the European Society for Environmental History Prague 2003, Charles University, Prague, pp. 246-256.

DORN, E. (1997): Schulgeschichte Philipsreuth. In: Dorn. E. (ed.): Heimat an der Grenze. Philipsreuth. Gemeinde Philipsreuth, Tittling, pp. 429-458.

EVANS, A. W. (2004): Economics and Land Use Planning. Blackwell Publishing, Oxford, 209 pp.

GABROVEC, M., PETEK, F. (2003): Changes in Land Use in the Border Zone of Slovenia and Austria - the Case of the Svečinske Gorice Hills. In: Jeleček, L. (ed.): Dealing with Diversity. Proceedings 2nd International Conference of the European Society for Environmental History Prague 2003, Charles University, Prague, pp. 237-241.

GION, W. (1997): Landwirtschaft. In: Dorn. E. (ed.): Heimat an der Grenze. Philipsreuth. Gemeinde Philipsreuth, Tittling, pp. 239-248.

HEAD, L. (2000): Cultural Landscapes and Environmental Change. Arnold/Oxford University Press, London-New York, 199 pp.

HOFFARTH, M. (2005): Der ländliche Grenzraum als Verflechtungsraum? Perspektiven einer grenzüberschreitenden, nachhaltigen Entwicklung in den Gemeinden Philipsreuth (D) und Strážný. Schriften für Raumordnung und Landesplanung, 19, Augsburg - Kaiserslautern.

HAVERSATH, J. B. (1995): Die neuzeitliche Besiedlung der Randgebirge des Böhmischen Beckens. In: Rother, K. (ed.): Mitteldeutschland gestern und heute. Passau, pp. 81-82.

KOLEJKA, J. (1983): Hodnocení změn krajiny z hlediska životního prostředí. PhD thesis. Geografický ústav ČSAV, Brno, 168 pp.

KOLEJKA, J. (1987): Landscape-historical synthesis. Materials, methods and results. Ecology (CSSR), 6, pp. 51-62.

KUPKOVÁ, L. (2001): Data o krajině včera a dnes. 160 let ve tváři české kulturní krajiny. Geoinfo, 8, pp. 16-19.

LIPSKÝ, Z. (1995): The changing face of the Czech rural landscape. Landscape and Urban Planning, 31, pp. 39-45. 
LOVEJOY, D. (ed.) (1973): Land Use and Landscape Planning. Leonard Hill Books, Aylesbury, $308 \mathrm{pp}$.

MATHER, A. (2002): The reversal of land-use trends: the beginning of the reforestation of Europe. In: Bičík, I., Chromý, P., Jančák, V., Janů, H. (eds.): Land use/land cover changes in the period of globalization. Proceedings of the IGU-LUCC International Conference Prague 2001, Charles University, Prague, pp. 23-30.

NAVEH, Z., LIEBERMAN, A. (1994): Landscape Ecology. Theory and Application, second ed., Springer Verlag, New York-Berlin-Heidelberg. 203 pp.

OLAH, B. (2003): Vývoj využitia krajiny Podpolania. Starostlivost' o kultúrnu krajinu prechodnej zóny Biosférickej rezervácie Polana. Vedecké štúdie, 1, pp. 1-111.

PRAXL, P. (1997): Die Strasse nach Böhmen. In: Dorn. E. (ed.): Heimat an der Grenze. Philipsreuth. Gemeinde Philipsreuth, Tittling, pp. 175-194.

ŠTĚPÁNEK, V. (2002): Czech frontier in the 20th century: major political shifts reflected in changing land use structure. In: Bičík, I., Chromý, P., Jančák, V., Janů, H. (eds.): Land use/land cover changes in the period of globalization. Proceedings of the IGU-LUCC International Conference Prague 2001, Charles University, Prague, pp. 110-115.

ŠTYCH, P. (2003): Hodnocení vlivu nadmořské výšky na vývoj změn využití půdy Česka 1845, 1948 a 1990. In: Jančák, V., Chromý, P., Marada, M. (eds.): Geografie na cestách poznání. Sborník příspěvků k šedesátinám Ivana Bičíka. Univerzita Karlova, Praha, pp. 59-70.

ZHANG, B. (2002): The change of swampy wetland in northeast China. In: Bičík, I., Chromý, P., Jančák, V., Janů, H. (eds.): Land use/land cover changes in the period of globalization. Proceedings of the IGU-LUCC International Conference Prague 2001, Charles University, Prague, pp. 75-80.

\section{Shrnutí}

\section{KONVERGENCE KULTURNÍ KRAJINY U ČESKO-BAVORSKÉ HRANICE NA ŠUMAVĚ}

Dvě modelové obce u česko-bavorské hranice byly zvoleny ke studiu změn kulturní krajiny. Cílem výzkumu bylo zjištění změn využití krajiny v různých typech přírodního prostředí po obou stranách hranice v průběhu posledních 200 let $\mathrm{s}$ ohledem na působení sociálních hnacích sil v pozadí. Úkol se opíral o provedení historického výzkumu archivních materiálů, terénního výzkumu a nakonec o zpracování dat v prostředí GIS. V GIS byly geostatisticky vyhodnoceny postupně sestavené mapy využití krajiny v letech 1829-1840, 1935-1938 a 2002-2007 jak mezi sebou, tak nad mapou typologických přírodních krajinných jednotek na topické úrovni členění krajiny. Získané mezivýsledky prostorového a statistického charakteru byly dále použity $\mathrm{k}$ posouzení forem a intenzity využívání jednotlivých typů přírodních krajinných jednotek. Bylo zjištěno, že analogické typy přírodních krajinných jednotek po obou stranách hranice vykazují přes odlišné startovní podmínky, dané rozdílnou úrovní společenského a hospodářského rozvoje a odlišný průběh vývoje, nakonec v současnosti podobnou strukturu, tedy podobné zastoupení hlavních a fyziognomických forem využití: lesa, luk a pastvin a orné půdy, částečně zástavby a přibližně i podobný vzhled. Metodou shlukové analýzy byly odhaleny základní vývojové trendy, odpovídající plošnému zastoupení oněch hlavních forem využití, ve všech místních typech přírodních krajinných jednotek. Ukazuje se, že v zásadě v daném území působí 5 typů vývojových trendů „land use“ (A-E) na pozadí jednotlivých typů přírodního prostředí, z nichž čtyř̀i $(A, B, C$ a D) jsou výrazně početně v obou územích zastoupeny. Především trendy typu $\mathrm{A}, \mathrm{C}$ a D vedou k výrazné konvergenci využití jednotlivých typů prostředí reprezentovaných typy př́írodních krajinných jednotek v současnosti. U typu B je tendence ke konvergenci zřetelná částečně. Změny využití krajiny v obou zájmových územích byly dány do souvislosti s obecnou politickou a ekonomickou situací panující ve sledovaných územích ve zkoumaných letech. Po obou stranách státní hranice tak dochází také ke konvergenci struktury využití krajiny, což se projevuje i ve sbližování vzhledu krajiny díky podobným přírodním poměrům. Tento jev pravděpodobně souvisí s postupně se vzájemně blížícím zájmům o hospodářské využití obou území, ačkoliv životní styl je zatím stále odlišný. Na německé straně převládá lesní hospodářství, individuální farmářství 
v oboru živočišné výroby a aktivity spojené s rekreací a zimními sporty. Na české straně vedle podružné živočišné výroby v chráněném území NP Šumava dominuje lesní hospodářství (mimo 1. a 2. zóny NP). Vysoká zaměstnanost je ve sféře obchodu, zábavy (kasino) a erotické turistiky. Tomu odpovídá také odlišný vztah obyvatel obou území k místům bydlení a životních perspektiv. Zdá se tedy, že ačkoliv v minulosti v obou územích působily střídavě zcela odlišné hospodářsko-politické poměry, výsledný efekt na krajinu, měřený charakterem využití ploch, je velice podobný. To svědčí o zřetelném vlivu př́rodních poměrů a obecně platné tendenci $\mathrm{k}$ co nejefektivnějšímu využívání odpovídajícímu dané době. Konvergence struktury využití ploch, vzhledu v rámci analogických typů přírodních krajinných jednotek po obou stranách krajiny přináší jisté riziko ztráty individuality původně charakteristických kulturních krajin. Ty původně jedna pro obyvatele druhé představovaly jistou míru atraktivity, pro návštěvníky z jiných území tak klesá pestrost pohraniční oblasti. Otázkou je, zda podobná konvergence jiných krajin s podobnými př́rodními podmínkami nevede ke ztrátě kulturní identity a diversity ve spojeném evropském prostoru, což může být v rozporu $\mathrm{s}$ širšími zájmy EU v oblasti zachování krajinné rozmanitosti.

Obr. 1 - Poloha studovaného území na česko-německé hranici (CZ - Česko, D - Německo).

Obr. 2 - Sídelní jednotky obou sousedících obcí na česko-bavorském pomezí (CZ - Česko, D - Německo). V legendě: lokální centrum, existující sídlo, opuštěné sídlo.

Obr. 3 - Typy přírodních krajinných jednotek studovaného území představující typy přírodního prostředí pro výběr a vývoj využití ploch (legenda viz tab. 1).

Obr. 4 - Relativní zastoupení typů přírodních krajinných jednotek v katastrech obou příhraničních obcích ( $\mathrm{v} \% \mathrm{z}$ celkové plochy každého z obou studovaného území).

Obr. 5 - Využití krajiny v katastrech obou sousedících obcí v letech 1829-1840. V legendě: lesy, vodní plochy, pastviny, orná půda, zastavěné plochy, komunikace.

Obr. 6 - Využití krajiny v katastrech obou sousedících obcí v letech 1935-1938. Legenda viz obr. 5.

Obr. 7 - Využití krajiny v katastrech obou sousedících obcí v letech 2002-2007. Legenda viz obr. 5.

Obr. 8 -Diagram odlišných úrovní přesnosti lokalizace poznatků o změnách využití krajiny.

Obr. 9 - Plochy beze změny využití v průběhu sledovaného období. V legendě: lesy, pastviny, orná půda.

Obr. 10 - Vývoj hlavních forem využití v obou příhraničních územích jako celcích (v \% z celkové plochy každého obou studovaného území).

Obr. 11 - Konvergence vzhledu obou příhraničních území je mj. dána společným příklonem k rekreaci a zimním sportům (vlevo - Philipsreuth, vpravo Strážný).

Obr. 12 - Procentuální zastoupení hlavních forem využití krajiny v jednotlivých typech přírodních krajinných jednotek za jednotlivé sledované časové horizonty v obou sledovaných územích - Philipsreuth (vlevo) a Strážný (vpravo). Čísla označují jednotlivé typy přírodních krajinných jednotek, jejichž popisy jsou uvedeny v tabulce 1. V legendě: lesy, pastviny, orná půda.

Obr. 13 - Podobnost vývoje využití ploch ve dvou vybraných typech přírodních krajinných jednotek v obou příhraničních územích vede ke vzhledové a funkční konvergenci ( $v \%$ z celkové plochy daného typu). V legendě: lesy, pastviny, orná půda.

Obr. 14 -Dendrogram klasifikace přírodních krajinných jednotek z pohledu vývojových trendů využití ploch $\mathrm{v}$ obou příhraničních územích za využití shlukové analýzy (D - Philipsreuth, CZ - Strážný).

Obr. 15 - Typický průběh vývoje využití ploch ve čtyřech (z celkem 5) skupin typů přírodních krajinných jednotek. Cleny skupin znázorňuje dendrogram v obrázku 14. Konvergentní vývoj „land use“ je výrazný u skupin A, C a D, částečně ve skupině B. (Hodnoty $\mathrm{v} \%$ označují podíl na celkové ploše typu.)

Obr. 16 - Územní rozmístění přírodních krajinných jednotek náležejících jednotlivým skupinám vývojových trendů zjištěných během posledních dvou století ( $\mathrm{A}-\mathrm{D}$, vývojové trendy popsané v obrázku 15, trend E vykazuje pouze 1 případ). 
T. Breuer is affiliated with Universität Regensburg, Lehrstuhl für Kulturgeographie, 93040 Regensburg, Germany; e-mail: toni.breuer@geographie.uni-regensburg.de.J. Kolejka is affiliated with Masaryk University, Faculty of Education, Department of Geography, Pořiči 7, 60300 Brno, Czechia, e-mail: kolejka@ped.muni.cz. D. Marek is affiliated with Charles University in Prague, Faculty of Science, Department of Physical Geography and Geoecology, Albertov 6, 12843 Praha 2, Czechia, e-mail: daniel.marek@centrum.cz. E. Werner is affiliated with Universität Regensburg, Institut für Geographie, 93040 Regensburg, Germany, e-mail: ekkehard.werner@geographie.uni-regensburg.de.

Initial submission 15 November 2009; final acceptance 3 May 2010

\section{Citační vzor:}

BREUER, T., KOLEJKA, J., MAREK, D., WERNER, E. (2010): Convergence of cultural landscape in the Czech-Bavarian border in Šumava Mts. Geografie, 115, č. 3, s. 308-329. 